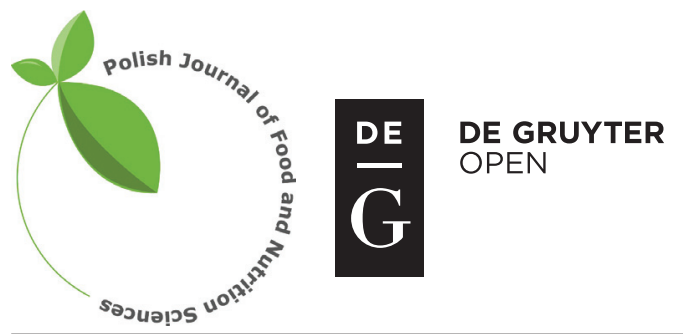

Pol. J. Food Nutr. Sci., 2017, Vol. 67, No. 2, pp. 95-105

DOI: $10.1515 /$ pjfns-2016-0028 http://journal.pan.olsztyn.pl

Review article

Section: Nutrition Section

\title{
Potential Health Implications of the Consumption of Thermally-Oxidized Cooking Oils - a Review
}

\author{
Ayodeji Osmund Falade ${ }^{1,2 *}$, Ganiyu $\mathrm{Oboh}^{3}$, Anthony Ifeanyi Okoh ${ }^{1,2}$ \\ ${ }^{I}$ SAMRC Microbial Water Quality Monitoring Centre, University of Fort Hare, \\ Private Bag X1314, Alice, 5700, Eastern Cape, South Africa \\ ${ }^{2}$ Applied and Environmental Microbiology Research Group (AEMREG), Department of Biochemistry and Microbiology, \\ University of Fort Hare, Private Bag X1314, Alice, 5700 Eastern Cape, South Africa \\ ${ }^{3}$ Functional Foods and Nutraceuticals Unit, Department of Biochemistry, Federal University of Technology, \\ P. M.B. 704, Akure, 340252, Nigeria
}

Key words: thermal oxidation, cooking oils, antioxidant properties, health concerns

Cooking oils are an integral part of a human diet as they are used in almost all types of culinary practices. They serve as sources of lipids with a significant nutritive value and health benefits which can be attributed to their fatty acid compositions and biological antioxidants. However, cooking oils are usually subjected to thermal oxidation which occurs when fresh cooking oil is heated at high temperatures during various food preparations. Repeated use of cooking oils in the commercial food industry is also common to maximize profit. Thermal oxidation of edible oils had since attracted great attention of nutritionist and researchers given the deteriorative effect such as generation of very cytotoxic compounds, loss of carotenoid, phenolics and vitamins thus reducing the overall antioxidant properties of the oils. Furthermore, several in vivo studies had suggested that consumption of thermally-oxidized cooking oils might not be healthy as it might negatively influence the lipid profile (increased low density lipoprotein (LDL), decreased high density lipoprotein (HDL) and elevated cholesterol level), haematological system (alteration in concentration of heamoglobin (Hb), packed cell volume (PCV), white blood cell (WBC) count, neutrophil and lymphocyte counts), kidney function, and induce lipid peroxidation and oxidative stress which have been associated with the pathogenesis of various degenerative diseases. Therefore, thermal oxidation seems not to provide any health benefit, as it deteriorates cooking oils and the consumption of the oils may predispose consumers to various disease conditions that may ensue from free radical generation, thereby having deleterious effect on human health.

\section{INTRODUCTION}

Cooking oils are an integral part of a human diet as they are used in almost all types of food preparations including frying, baking, sautéing, dressing, marinades and extrusion cooking. There are various types of cooking oils classified based on their different sources, examples include palm oil, arachis oil (peanut/groundnut oil), coconut oil, avocado oil, fish oil, flax oil, soybean oil, canola oil, sunflower oil, olive oil, corn oil, sesame oil and other vegetable oils. Cooking oils are an indispensable part of our daily diet because they serve as sources of lipid which is an important source of energy, a major part of biomembrane [Vaskova \& Buckova, 2015] and serve as building blocks for several hormones. Furthermore, the nutritive value and health benefits of these oils are enormous and this can be attributed to their respective constituents such as fatty acid composition (the proportion of saturated to unsaturated fats; and monounsaturated to polyunsaturated fats) and types of natural antioxidants in-

\footnotetext{
* Corresponding Author: Tel.: +27 (0) 785927884;

E-mail: ayodeji.falade@yahoo.com, 201508654@ufh.ac.za (A. O. Falade)
}

cluding vitamin $\mathrm{A}$, vitamin $\mathrm{E}$ and carotenoids which protect cells and tissues from being damaged by free radicals.

Cooking oils are either consumed fresh or thermally oxidized [Oboh et al., 2014], but mostly thermally oxidized. Thermal oxidation occurs when the fresh form of cooking oils is heated at high temperatures during various food preparations to increase palatability [Oboh et al., 2014]. Thermal oxidation is a usual domestic practice in Africa [Oboh et al., 2014; Falade \& Oboh, 2015] to improve organoleptic properties of food [Warner, 2004]. This practice is not limited to various homes; it is also a regular practice in restaurants and commercial food industry where deep-fat frying and baking occur at very high temperatures. In the commercial food industry, reuse of cooking oils over a period of time is common in order to maximize profit.

During cooking, various chemical reactions occur including thermal oxidation, due to oil exposure to high temperatures in the presence of air and moisture. Consequently, cooking oil disintegrates and generates volatile compounds; different monomers and polymers [Andrikopoulos et al., 2002]. Some of the major factors that influence the value of cooking oil in the course of food preparations include temperature, heating period, oil type, level of saturation, and the presence of antioxidant [Gupta, 2005]. 
Heating cooking oil beyond a particular temperature may change its physicochemical characteristics [Oboh et al., 2014; Falade \& Oboh, 2015]. However, the resistance and stability of different cooking oils to thermal oxidation varies as this is dependent on their fatty acid compositions, wherein oils with higher polyunsaturated fatty acids are more prone to thermal oxidation [Vaskova \& Buckova, 2015], those with higher saturated fat such as palm oil are capable of withstanding heat at high temperatures [Matthaus, 2007].

The mechanistic operation of thermal oxidation is said to be similar to that of autooxidation. However, the rate of thermal oxidation is faster [Choe \& Min, 2007] and occurs through a free radical mechanism of chain reactions which involve initiation, propagation and termination.

Moreover, studies have revealed that thermal oxidation has a deteriorative effect on cooking oils [Peers \& Swoboda, 1982; Oboh et al., 2014], but despite these reports the practice seems to persist. Therefore, this review gives an overview of some commonly consumed cooking oils, the effects of thermal oxidation on their nutritional qualities and the possible health implications.

\section{SELECTED COMMON COOKING OILS}

\section{Palm oil}

Palm oil is an extract from the ripe mesocarp of the oil palm fruits (Elaeis guineensis) with Indonesia, Malaysia, Thailand, Colombia and Nigeria as the leading producers in the world [Mba et al., 2015].

Palm oil is a notable source of cooking oil in various countries, especially in Africa and Asia [Ong \& Goh, 2002; Onyeali et al., 2010; Oyewole \& Amosu, 2010; Odia et al., 2015] and has continued to enjoy increased patronage in recent times as it is reportedly free of trans-fats [Mukherjee \& Mitra, 2009]. According to Oil World [2013], palm oil is reported to have overtaken soybean oil in the world's market. It is described as the richest source of carotenoids, which is significantly more than that in carrots [Mukherjee \& Mitra, 2009]. Carotenoids play important roles as biological antioxidants, protecting the body cells against reactive oxygen species (ROS) and lipid peroxidation which has been associated with a number of pathology including cancer, cardiovascular disease and type-2-diabetes. The high content of the carotenoids in palm oil seems to compensate for the "so called" high saturated fatty acid composition (50\%) which had since stigmatized palm oil as a saturated fat being avoided by potential consumers thereby ignorantly losing the potential health benefits of palm oil. Besides the antioxidant role of carotenoids in palm oil, they are also precursors of vitamin A, a fat-soluble vitamin with major roles in the regulation of many biological and metabolic functions such as growth, reproduction, regulation of immune system and cell differentiation. In addition to carotenoids and vitamin A, palm oil also contains vitamin E (tocotrienols) which possess powerful antioxidant property and are capable of inhibiting cholesterol synthesis [Chong \& $\mathrm{Ng}, 1991$; Odia et al., 2015].

Palm oil is unique in its fatty acid composition as it is the only cooking oil with approximately equal composition of saturated (50\%) and unsaturated fatty acids (50\%) [Chong
\& Ng, 1991; Mba et al., 2015]. Its major saturated fatty acid component is palmitic acid (C-16) with its name derived from palm. Other major fatty acid components of palm oil are oleic acid (C-18: monounsaturated), linoleic acid (C-18: polyunsaturated) while the minor ones include myristic acid (C-14) and stearic acid (C-18). However, a WHO report has associated consumption of palmitic acid with an increased risk of cardiovascular diseases [World Health Organization, 2003]. In a recent review by Odia et al. [2015], the authors opined that dietary palm oil as part of a healthy balanced diet does not increase the risk of cardiovascular disease.

\section{Arachis oil}

Arachis oil is a kind of cooking oil obtained from groundnuts or peanuts and has been described as one of the most frequently consumed vegetable oils in Nigeria with high smoking point which encourages its use in frying [Falade \& Oboh, 2015].

Arachis oil is a rich source of mono-unsaturated fatty acids (MUFA) such as oleic acid (18:1) which lowers LDL cholesterol, the so called "bad cholesterol" and increases HDL cholesterol also referred to as "good cholesterol" in the blood. Specifically, its major fatty acid components include oleic acid (46.8\% olein), linoleic acid (33.4\% linolein), palmitic acid (10\% palmitin) [USDA, 2008]. It is also made up of the following acids: arachidic, arachidonic, behenic, lignoceric, stearic and some other fatty acids [Falade \& Oboh, 2015]. Its low saturated fat and high content of essential fatty acids makes it one of the healthiest cooking oils. Nonetheless, its high proportion of unsaturated fats makes it vulnerable to thermal oxidation. Arachis oil contains a significant amount of vitamin $\mathrm{E}$ and an insignificant concentration of carotene [Falade \& Oboh, 2015]. Vitamin E is a strong antioxidant. All its isomers (tocopherols and tocotrienols) possess good antioxidant properties in vitro, with tocotrienols being the most potent [Seppanen et al., 2010]. Tocopherols are capable of scavenging lipid peroxyl radicals $\left(\mathrm{ROO}^{\circ}\right)$, the species that propagate lipid peroxidation as follows:

$$
\mathrm{ROO}^{\bullet}+\mathrm{TOH} \rightarrow \mathrm{ROOH}+\mathrm{TOO}^{\bullet}
$$

where ROO• - lipid peroxyl radical, TOH - tocopherol, and $\mathrm{TOO}^{\bullet}$ - tocopheroxyl radical.

Even though vitamin E possesses powerful antioxidant properties, it is also prone to thermal oxidation.

\section{Soybean oil}

Soybean oil is a kind of cooking oil derived from soybean seeds and has been described as one of the most widely and commonly consumed vegetable oils.

Its fatty acid composition is its selling point as it contains a high proportion of unsaturated fatty acids, comprising of alpha-linolenic acid, C-18:3 (7-10\%), linoleic acid, C-18:2 (51\%) and oleic acid, C-18:1 (23\%) [Ivanov et al., 2010]. It also includes the following saturated fats: $4 \%$ stearic acid (C-18:0) and 10\% palmitic acid (C-16:0).

Although the high level of linolenic acid, a polyunsaturated fatty acid (PUFA), in soybean oil is desirable, it is highly prone to oxidation and therefore unpleasant for some uses 
such as cooking and frying at high temperatures. To overcome this challenge, hydrogenation has been used to decrease the level of unsaturation in linolenic acid resulting in hydrogenated soybean oil.

\section{Canola oil}

Canola is one of the mostly patronized edible oils produced from the seed of any of the different varieties of rape plant including cultivars of Brassica napus L. and Brassica rapa. Canola oil is most desirable for cooking due to its very low saturated fatty acid composition of about 7\% [USDA, 2008; Katragadda et al., 2010] which is the least in any common cooking oil, less than half the saturated fat of arachis oil and soybean oil; and almost half of that of olive oil. It has an appreciable amount of all the omega fatty acids (omega-3,-6, -9) but is specifically rich in omega-9 fatty acid with $61 \%$ oleic acid. Other major fatty acid constituents of canola oil include $21 \%$ linoleic acid and 9\% alpha-linolenic acid [USDA, 2008]. It also contains minor constituents such as palmitic acid (4\%) and stearic acid (2\%). Its consumption has been reported to reduce LDL and total cholesterol levels. Omega-3 fatty acid, an essential fatty acid, has been associated with reduced cardiovascular mortality [O'Brien, 2008]. It has also been suggested to play important roles in brain function and fight against cardiovascular disease [Wang et al., 2006] whereas omega-9 is a non-essential fatty acid synthesized naturally by the body where there is enough essential fatty acid (omega-3 or omega-6). Consequently, when the body suffers from inadequate essential fatty acids, dietary omega- 9 fatty acid is required, hence the significance of canola oil as a rich source of omega- 9 with roles in heart health and improved immune function.

A recent clinical trial conducted by Salar et al. [2016] on the effect of substitution of rice bran oil and canola oil for sunflower oil in women with type-2 diabetes showed that substitution of canola oil for sunflower oil could improve blood lipid profile in type-2 diabetic patients. Furthermore, the hypolipidemic effect of canola oil has been reported [Innis \& Dyer, 1999; Dittrich et al., 2015]. The hypolipidemic properties of canola oil may be associated with its high content of MUFA and omega-3 fatty acids [Salar et al., 2016].

\section{Olive oil}

Olive oil is derived from the fruit of olive (Olea europaea). It is composed of oleic, linoleic, palmitic, stearic and $\alpha$-linolenic acids. However, the proportion varies by cultivars, extraction process and time of harvest. It is abundant in MUFA (oleic acid) representing 70-80\% of its total fatty acids [Tripoli et al., 2005]. An increased consumption of MUFA has been reported to reduce the risk of atherosclerosis [Tripoli et al., 2005]. Olive oil has a high oxidative stability during frying at high temperatures when compared with some other cooking oils such as soybean oil, sunflower oil, arachis oil, corn oil etc. [Boskou, 2006], hence its lower rate of alteration. Its oxidative stability and resistance to deterioration at high temperatures can be ascribed to its fatty acid constitution, especially its low amount of PUFA and the presence of biological antioxidants including alpha-tocopherol, delta-5 avenasterol and squalene [Blekas \& Boskou, 1999; Boskou, 2006].
These unique characteristics informed the preference for olive oil in frying process. The beneficial effects of olive oil against cancer, diabetes, inflammatory diseases including rheumatoid arthritis have been established as well [Owen et al., 2000; Alarcon de la Lastra et al., 2001; Tripoli et al., 2005]. Hypolipidemic activity of olive oil has also been reported [Nakbi et al., 2012]. The health benefits of olive oil have been attributed to the antioxidant property of its phenolics [Tripoli et al., 2005]. Olive oil contains about 30 phenolic compounds [Attya et al., 2010] which include but are not limited to the following: simple phenolics such as vanillic acid, gallic acid, coumaric acid, caffeic acid, tyrosol and hydroxytyrosol; and some more complex ones (secoiridoids and lignans) [Tripoli et al., 2005].

The antimicrobial, antioxidant and anti-inflammatory activities of olive oil phenolics have been further confirmed in a review by Cicerale et al. [2012] as the consumption of extra virgin olive oil has been linked with a lower incidence of chronic degenerative diseases and higher life expectancy observed within the Mediterranean populations [Cicerale et al., 2012].

\section{Sunflower oil}

Sunflower oil, derived from the seeds of sunflower (Helianthus annuus) is commonly used for frying and other culinary practices. Sunflower oil is a rich source of PUFA (linoleic acid) which constitute about $59 \%$ of the oil. Other fatty acid constituents of sunflower oil include oleic acid (MUFA); palmitic and stearic acids (saturated fatty acids). Although the high proportion of PUFA in sunflower compared to other oils in this review is considered an advantage given its health benefits, it enhances its susceptibility to thermal oxidation [Sadoudi et al., 2014]. The heating of PUFA in the presence of air has been reported to cause a greater degree of lipid peroxidation [Sadoudi et al., 2014] which has been implicated in human health and disease [Ramana et al., 2013].

\section{UNDERUTILIZED EDIBLE OILS}

There is an increasing research effort towards exploration of underutilized edible oils such as linseed oil (flaxseed oil), borage oil, camelina oil, amaranth oil and milk thistle oil as nutritional supplements due to their medicinal and health attributes. They serve as sources of fatty acids when added to thermally-processed food products including extruded products and baking products which are usually characterized by a low nutritional value and low PUFA content. For instance, Szterk et al. [2015] and Rogalski \& Szterk [2015] created functional corn crisps enriched in $n-3$ fatty acids through addition of linseed oil.

\section{EFFECTS OF THERMAL OXIDATION ON THE QUALITY OF COOKING OILS}

Thermal oxidation of cooking oils is a normal day-to-day practice in homes and commercial food industries where edible oils are used for various types of cooking at different temperatures ranging from low to very high. Temperature has been described as one of the major factors that influence the quality of edible oils [Gupta, 2005]. 
TABLE 1. Summarized effects of thermal oxidation on the quality of cooking oils.

\begin{tabular}{|c|c|c|c|c|c|}
\hline $\begin{array}{l}\text { Cooking oil } \\
\text { studied }\end{array}$ & $\begin{array}{c}\text { Temp of oxidation } \\
\left({ }^{\circ} \mathrm{C}\right)\end{array}$ & Duration & Effects on physicochemical properties & & References \\
\hline Olive oil & 180 & $1.5-25 \mathrm{~h}$ & $\begin{array}{l}\text { Hydroxytyrosol- } \& \text { tyrosol- } \\
\text { like substances. } \\
\text { Degradation of } \alpha \text {-tocopherol } \\
\text { and glyceridic fractions. } \\
\text { Minor losses in polyphenols. }\end{array}$ & $\downarrow$ & Brenes et al. [2002] \\
\hline $\begin{array}{l}\text { Olive, corn, } \\
\text { soybean oils }\end{array}$ & 180 & $30,60,90 \mathrm{mins}$ & $\begin{array}{l}\text { Peroxide value } \\
p \text {-anisidine value } \\
\% \text { FFA }\end{array}$ & $\uparrow$ & Naz et al. [2005] \\
\hline Olive oil & 180 & $30-180$ mins & $\begin{array}{l}\text { Concentration of hydroxytyrosol, } \\
\text { elenolic acid, decarboxymethyl } \\
\text { oleuropein aglycon, } \\
\text { and oleuropein aglycon. }\end{array}$ & $\downarrow$ & Carrasco-Pancorbo et al. [2007] \\
\hline $\begin{array}{l}\text { Palm oil } \\
\text { and soy oil }\end{array}$ & 180 & $\begin{array}{c}\text { Heated once \& } \\
5 \text { times (10 mins) }\end{array}$ & $\begin{array}{l}\text { Vitamin E content } \\
\text { Various Vitamin E isomers }\end{array}$ & $\downarrow$ & Adam et al. [2007] \\
\hline Canola oil & $185 \& 215$ & 7 h/day (7 days) & $\begin{array}{l}\text { Total polar compounds ( } 16 \% \& 38 \%) \\
\text { Anisidine value } \\
\text { Tocopherol degradation }\end{array}$ & $\begin{array}{l}\downarrow \\
\uparrow \\
\end{array}$ & Aladedunye \& Przybylski [2009] \\
\hline $\begin{array}{l}\text { Coconut, } \\
\text { safflower, canola } \\
\& \text { olive oil }\end{array}$ & $180,210,240,270$ & $6 \mathrm{~h}$ & $\begin{array}{l}\text { Formation of acrolein increased } \\
\text { with temperature. }\end{array}$ & & Katragadda et al. [2010] \\
\hline $\begin{array}{l}\text { Sunflower, grape } \\
\text { seed, soybean, } \\
\text { corn \& olive oil }\end{array}$ & 180 & $50 \mathrm{~h}$ & $\begin{array}{l}\text { Conjugated trienes and total } \\
\text { polar components. }\end{array}$ & $\uparrow$ & Marinova et al. [2012] \\
\hline Sunflower oil & 100 & $52 \mathrm{~h}$ & Essential fatty acid (linoleic acid) & $\downarrow$ & Sadoudi et al. [2014] \\
\hline \multirow{3}{*}{ Palm oil } & \multirow{3}{*}{$30-320$} & \multirow{3}{*}{$0-20$ mins } & MDA content & $\uparrow$ & \multirow{3}{*}{ Oboh et al. [2014] } \\
\hline & & & Carotenoid content & $\downarrow$ & \\
\hline & & & Iodine value & $\uparrow$ & \\
\hline \multirow{3}{*}{ Arachis oil } & \multirow{3}{*}{220} & \multirow{3}{*}{20 mins } & $\begin{array}{l}\text { Acid value, Peroxide value } \\
\text { MDA concentration }\end{array}$ & $\uparrow$ & \multirow{3}{*}{ Falade \& Oboh [2015] } \\
\hline & & & Total carotenoid & & \\
\hline & & & Total $\beta$-carotene & $\downarrow$ & \\
\hline
\end{tabular}

Symbol interpretation: $\uparrow$ - increased; $\downarrow$ - decreased; $\uparrow$ - no changes.

The interest in the subject of thermal oxidation has continued to increase, given the deteriorative effect it might have on the quality of cooking oils. The impact of thermal oxidation on the quality of cooking oils has been studied [Naz et al., 2005; Adam et al., 2007; Carrasco-Pancorbo et al., 2007; Attya et al., 2010; Marinova et al., 2012; Oboh et al., 2014; Sadoudi et al., 2014; Falade \& Oboh, 2015]. However, the effect of thermal oxidation on the quality of cooking oils cannot be overemphasized due to the significance of cooking oils in nutrition and health. There is therefore the need to accentuate the potential implications of deterioration of cooking oils on health.

Furthermore, the effect of thermal oxidation on the following quality and nutritional indices: physico-chemical properties, antioxidant properties, carotenoid contents, vitamin E content, phenolics content etc. has continued to gain increased attention of nutritionist and researchers. Table 1 summarizes the effects of thermal oxidation on the quality of some cooking oils.

A previous study by Naz et al. [2005] investigated the deterioration of olive, corn and soybean oils caused by exposure to air, light, heat and deep-fat frying. The oils used in the study were used for deep-frying of potatoes at $180^{\circ} \mathrm{C}$ for
30, 60 and 90 mins. The study showed an increase in the oxidative deterioration indicators (peroxide and $p$-anisidine values) with the highest observed in deep-fat frying, as soybean oil was reported as the most prone to oxidation in the study. Meanwhile the \% free fatty acids (\% FFA) increased with an increase in time of deep-frying, which was attributed to hydrolysis. Furthermore, Aladedunye \& Przybylski [2009] assessed the effect of frying temperature on the degradation of canola oil. The canola oil in the study was heated at $185^{\circ} \mathrm{C}$ and $215^{\circ} \mathrm{C}$ for $7 \mathrm{~h}$ daily for 7 days. The authors concluded that increasing frying temperature above $195^{\circ} \mathrm{C}$ could cause isomerization of PUFA thereby increasing the amount of trans isomers which have been described as unhealthy. Recently, in a study by Sadoudi et al. [2014], it was reported that thermal oxidation of sunflower oil at $100^{\circ} \mathrm{C}$ for $52 \mathrm{~h}$ caused deterioration of the oil leading to the development of oxidative rancidity. A significant loss in the essential fatty acid (linoleic acid) was also observed in the thermally-oxidized sunflower oil.

In one of our recent studies [Oboh et al., 2014], we investigated the effect of thermal oxidation on the physico-chemical properties, malondialdehyde (MDA) and carotenoid contents of palm oil. In the study, fresh palm oil was heated from 0 to 20 mins with the corresponding temperatures ranging from 
$33^{\circ} \mathrm{C}$ to $320^{\circ} \mathrm{C}$, respectively, and the effect on the physicochemical properties, MDA and carotenoid contents of the oil was evaluated. The study revealed that increase in the duration of thermal oxidation caused appreciable changes in the physico-chemical properties, increased MDA content and decreased the carotenoid content of the oil, thereby altering the nutritive and medicinal value of palm oil. In another study, Falade \& Oboh [2015] investigated the effect of thermal oxidation on lipid peroxidation, physico-chemical properties and $\beta$-carotene contents of arachis oil. The oil was heated for 20 mins with the temperature reaching $220^{\circ} \mathrm{C}$. It was discovered from the study that thermal oxidation induced lipid peroxidation and caused changes in the physico-chemical properties (acid, iodine, and peroxide values) and $\beta$-carotene content of arachis oil. The authors discouraged cooking and frying with arachis oil at a high temperature for a long period of time as this might cause a significant loss in the insignificant amount of $\beta$-carotene in the oil.

Marinova et al. [2012] investigated the high temperature performance of some cooking oils (sunflower oil, grape seed oil, soybean oil, corn oil, and olive oil) subjected to heating at a frying temperature of $180^{\circ} \mathrm{C}$ by evaluating the oxidative degradation of the oils. The study revealed that olive oil had better thermal oxidation stability which was attributed to its fatty acid composition. Also soybean and corn oils were reported as the most resistant to oxidation at frying temperatures [Marinova et al., 2012].

Furthermore, Adam et al. [2007] investigated the effect of repeated heating on the vitamin $\mathrm{E}$ content in palm oil and soy oil. The oils used in the study were heated once and five times with the temperature reaching $180^{\circ} \mathrm{C}$ while the heating lasted for 10 mins. The study suggested that heating reduced the various fractions of vitamin $\mathrm{E}$ in palm oil and soy oil. It is noteworthy that about $98 \%$ of the three most abundant vitamin $\mathrm{E}$ isomers ( $\alpha$-tocopherol, $\alpha$-tocotrienol, and $\gamma$-tocotrienol) in palm oil were lost to heating while up to $60 \%$ of $\gamma$-tocopherol (the most abundant form of vitamin $\mathrm{E}$ in soy oil) was destroyed by heating. The level of reduction was attributed to the degree of heating as the stability of vitamin $\mathrm{E}$ isomers varies during heating.

Brenes et al. [2002] in their study on the influence of thermal treatments on the polyphenol content of virgin olive oil using simulated cooking processes assessed the effect of these processes on the phenolic content and physicochemical characteristics of oils. In the study, frying was simulated by heating the oil at $180^{\circ} \mathrm{C}$ for $1.5,3,5,10,20$ and $25 \mathrm{~h}$. The study revealed that thermal oxidation at $180^{\circ} \mathrm{C}$ decreased significantly the hydroxytyrosol- and tyrosol-like substances. However, a high proportion of lignans 1-acetoxypinoresinol and pinoresinol was retained at $25 \mathrm{~h}$, thus suggesting the resistance of lignans to thermal oxidation. Moreso, rapid degradation of $\alpha$-tocopherol and glyceridic fractions of the oil was observed during thermal oxidation as microwave heating recorded minor losses in polyphenols. Interestingly, lignans also exhibited resistance during microwave heating.

In a similar study, Carrasco-Pancorbo et al. [2007] investigated the effect of thermal oxidation on the phenolic composition and antioxidant activity of extra virgin olive oil by studying the phenolic profile of the oil in the course of thermal oxidation at $180^{\circ} \mathrm{C}$ and different time intervals ranging from 30 to 180 mins. The concentration of phenolics belonging to the following classes of phenol (simple phenols, complex phenols, lignans, and phenolic acids) was evaluated. The study revealed a decrease in the concentration of hydroxytyrosol, elenolic acid, decarboxymethyl oleuropein aglycon, and oleuropein aglycon with thermal oxidation faster than other phenolics in the oil. However, hydroxytyrosol-acetate and ligstroside aglycone were reported to be quite resistant to heat treatment, while lignans exhibited an interesting behaviour as the family most resistant to thermal oxidation corroborating the previous claim by Brenes et al. [2002].

Katragadda et al. [2010] investigated the emissions of volatile organic compounds such as aldehydes generated by heating of some cooking oils including coconut, safflower, canola and olive oils at $180,210,240$ and $270^{\circ} \mathrm{C}$ for $6 \mathrm{~h}$. The study reported that emission of volatile compounds increased with oil temperature. Formation of Acrolein was observed in all the four cooking oils at even the lowest studied temperature $\left(180^{\circ} \mathrm{C}\right)$, suggesting domestic cooking as an indoor pollution challenge. This calls for special attention due to the carcinogenicity of acrolein. It is worthy of note that acrolein emission from safflower oil was higher than of the other three oils.

Furthermore, Harvorsen \& Blomhoff [2011] assessed the concentration of lipid oxidation products generated in twelve various vegetable oils oxidized by heating at $225^{\circ} \mathrm{C}$ for 25 mins to simulate a typical cooking situation. The concentration of alkenal found in the vegetable oils ranged from 33.24-119.04 nmol/mL. The authors further observed that heating caused a 2.9-11.2 fold increase in the alkenal concentration in the vegetable oils.

\section{HEALTH IMPLICATIONS OF THE CONSUMPTION OF THERMALLY-OXIDIZED COOKING OILS}

Formation of volatile organic compounds such as aldehyde, ketones, dienes and acids during degradation of edible oil induced by heating has been reported [Katraggada et al., 2010]. The oxidative degradation products do not only create unpleasant flavour or reduce the shelf life of cooking oils, they may also cause health challenges [Fullana et al., 2004]. Aldehydes are major degradation products with the ability to induce toxicological effects as a result of their reaction with amino groups of proteins [Katraggada et al., 2010]. Furthermore, aldehydes are capable of producing other volatile compounds such as MDA when undergone autooxidation. MDA is one of the reactive electrophile species that cause oxidative stress [Farmer \& Davoine, 2007]. Oxidative stress has been implicated in the pathogenesis of various degenerative diseases including cancer [Halliwell, 2007], Alzheimer disease [Pohanka, 2014], myocardial infarction [Ramond et al., 2013], kidney dysfunction [Massy et al., 2009], diabetes mellitus [Yang et al., 2011], and its complications [Giacco \& Brownlee, 2010]. The pathway showing the possible link between consumption of thermally-oxidized cooking oils and some pathology is given in Figure 1.

Besides alkanals, other more toxic unsaturated aldehydes such as alkenals and alkadienals have been reported [Meacher \& Menzel, 1999; Katragadda et al., 2010]. Given the formation of very cytotoxic compounds during thermal oxida- 


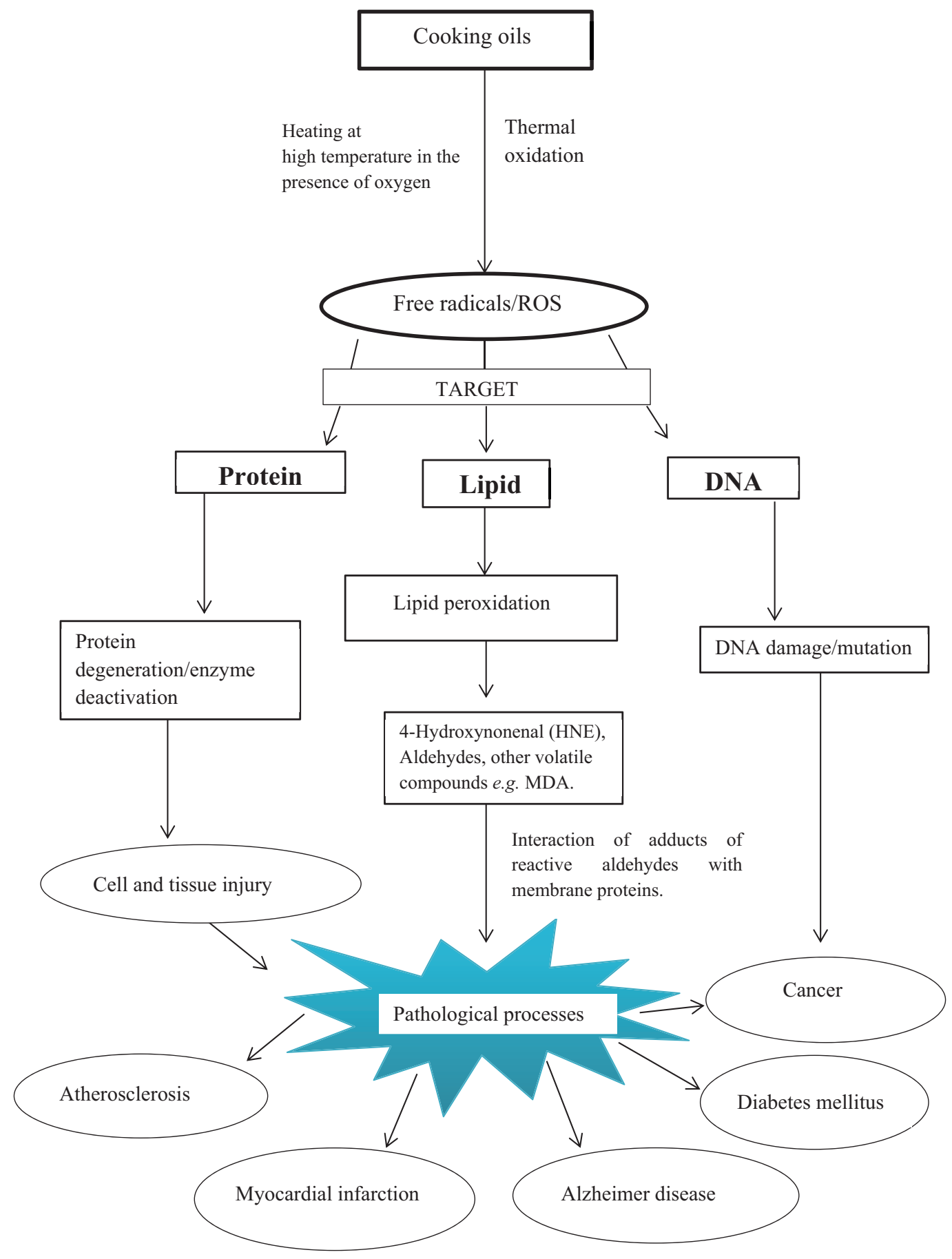

FIGURE 1. Pathway showing the link between consumption of thermally-oxidized cooking oils and some pathology.

tion, the effect of consumption of thermally-oxidized cooking oils on health has long been a concern. This review therefore accentuates the potential health implications of the consumption of thermally-oxidized cooking oils. Table 2 presents some potential health implications of consumption of thermally-oxidized cooking oils.

Several studies have established a link between thermally-oxidized cooking oils and digestibility [Márquez-Ruiz et al., 1992; Márquez-Ruiz et al., 1993; Olivero-David et al., 2011]. A recent review by Dorbaganes \& Márquez-Ruiz [2015] reported that frying oils and oils heated at frying temperatures decreased digestibility which they attributed to poor hydrolysis of triacylglycerol (TAG) polymers by pancreatic lipase. TAG polymers are dimers and oligomers generated by thermal oxidation and are specifically found in thermally-oxidized oils.

The effect of repeatedly heated palm oil on serum lipid profile, lipid peroxidation and homocysteine levels was investigated in a post-menopausal rat model by Adam et al. [2008a]. The study reported that repeatedly heated palm oil increases lipid peroxidation and total cholesterol. It was also suggested in the study that repeatedly heated oil is deleterious due to the fact that it causes oxidative damage thereby increasing the risk of atherosclerosis. A related study by Adam et al. [2008b] revealed that consumption of repeatedly heated soy 
TABLE 2. Potential health implications of the consumption of thermally-oxidized cooking oils

\begin{tabular}{|c|c|c|c|c|c|}
\hline $\begin{array}{l}\text { Thermally-oxidized } \\
\text { oil studied }\end{array}$ & Biochemical indices investigated & Findings of the study & & $\begin{array}{l}\text { Potential health } \\
\text { implications }\end{array}$ & References \\
\hline $\begin{array}{l}\text { Cooking oil } \\
\text { previously used } \\
\text { in deep-frying }\end{array}$ & $\begin{array}{c}\text { TBARS; } \\
\text { Fluorescent lipid oxidation } \\
\text { products (FLOP); } \\
\text { Plasma FFA; } \\
\text { Flow-mediated endothelium- } \\
\text {-dependent dilation; } \\
\text { Glyceryl/trinitrate-induced } \\
\text { endothelium-independent dilation } \\
\text { of branchial activity in healthy men }\end{array}$ & $\begin{array}{l}\text { TBARS } \\
\text { Endothelium-dependent dilation. } \\
\text { Endothelium-independent } \\
\text { dilation }\end{array}$ & $\begin{array}{l}\uparrow \\
\downarrow \\
\uparrow\end{array}$ & $\begin{array}{l}\text { Endothelial } \\
\text { dysfunction, an } \\
\text { important step } \\
\text { in the development } \\
\text { of atherosclerosis. }\end{array}$ & Williams et al. [1999] \\
\hline Palm oil & $\begin{array}{l}\text { Heamatological indices } \\
\text { (PCV, RBC, WBC \& Hb) }\end{array}$ & $\begin{array}{l}\text { PCV, RBC \& Hb. } \\
\text { WBC }\end{array}$ & $\begin{array}{l}\downarrow \\
\uparrow\end{array}$ & $\begin{array}{l}\text { Anaemia } \\
\text { and leukocytosis. }\end{array}$ & Mesembe et al. [2004] \\
\hline Soybean oil & $\begin{array}{l}\text { Serum TBARS; lipid } \\
\text { profile; homocysteine levels } \\
\text { in ovariectomized rats }\end{array}$ & TBARS , LDL, TCOL & $\uparrow$ & $\begin{array}{l}\text { Lipid peroxidation; } \\
\text { atherosclerosis; }\end{array}$ & Adam et al. [2008a] \\
\hline Palm oil & $\begin{array}{l}\text { Serum TBARS and lipid profile } \\
\text { in post-menopausal rats model }\end{array}$ & TBARS, TCOL & $\uparrow$ & $\begin{array}{c}\text { Oxidative damage; } \\
\text { atherosclerosis }\end{array}$ & Adam et al. [2008b] \\
\hline Soy oil & $\begin{array}{c}\text { Plasma nitric oxide (NO), Heme } \\
\text { oxygenase (HO-1), Angiotensin- } \\
\text {-Converting Enzyme (ACE), } \\
\text { Vascular reactivity }\end{array}$ & $\begin{array}{l}\text { Blood pressure } \\
\text { Higher plasma ACE } \\
\text { Lower NO and HO-1 concentration } \\
\text { Attenuated relaxation }\end{array}$ & 个 & $\begin{array}{l}\text { High blood } \\
\text { pressure }\end{array}$ & Leong et al. [2010] \\
\hline $\begin{array}{l}\text { Sunflower \& } \\
\text { palm oils }\end{array}$ & $\begin{array}{c}\text { Serum glutamate-pyruvate } \\
\text { transaminase (SGPT), } \\
\text { Serum glutamate-oxaloacetate } \\
\text { transaminase (SGOT), } \\
\text { ALP }\end{array}$ & $\begin{array}{l}\text { SGPT } \\
\text { SGOT } \\
\text { ALP } \\
\text { Histological study revealed } \\
\text { change in sizes of liver, heart, } \\
\text { kidney and testes cells. }\end{array}$ & $\begin{array}{l}\uparrow \\
\uparrow \\
\uparrow\end{array}$ & $\begin{array}{l}\text { Induction } \\
\text { of damage to } \\
\text { vital organs }\end{array}$ & Shastry et al. [2011] \\
\hline Palm and soy oils & $\begin{array}{c}\text { NO } \\
\text { Vascular reactivity }\end{array}$ & $\begin{array}{l}\mathrm{NO} \\
\text { Vascular contractile reactivity }\end{array}$ & $\begin{array}{l}\downarrow \\
\uparrow\end{array}$ & $\begin{array}{l}\text { High blood } \\
\text { pressure }\end{array}$ & Jaarin et al. [2011] \\
\hline Palm olein & TBARS; ACE; HO-1 & $\begin{array}{l}\text { TBARS } \\
\text { ACE activity } \\
\text { HO-1 activity }\end{array}$ & $\begin{array}{l}\uparrow \\
\downarrow\end{array}$ & $\begin{array}{l}\text { Lipid peroxidation; } \\
\text { hypertension }\end{array}$ & Leong et al. [2012] \\
\hline Coconut oil & $\begin{array}{c}\text { Blood pressure (BP) } \\
\text { Inflammatory biomarkers: } \\
\text { Intercellular adhesion molecule } \\
\text { (ICAM-1), Vascular cell adhesion } \\
\text { molecule (VCAM-1), C-reactive } \\
\text { protein (CRP), Prostacyclin } \\
\left(\text { PGI }_{2}\right) \text {, Thromboxane }(\mathrm{TXB})_{2} \text { ). } \\
\text { Lactate dehydrogenase (LDH) activity }\end{array}$ & $\begin{array}{l}\text { BP } \\
\text { ICAM-1, VCAM-1, } \text { PGI }_{2,} \text { TXB }_{2}\end{array}$ & $\begin{array}{l}\uparrow \\
\uparrow\end{array}$ & $\begin{array}{l}\text { High blood } \\
\text { pressure/ } \\
\text { hypertension; } \\
\text { inflammation }\end{array}$ & Hamsi et al. [2015] \\
\hline Palm oil & $\begin{array}{l}\text { Serum electrolyte, creatinine } \\
\text { and urea in rabbit }\end{array}$ & $\begin{array}{l}\text { Sodium ion } \\
\text { Chloride ion } \\
\text { Creatinine } \\
\text { Urea }\end{array}$ & $\begin{array}{l}\uparrow \\
\uparrow \\
\uparrow \\
\uparrow\end{array}$ & $\begin{array}{l}\text { Compromised } \\
\text { renal status }\end{array}$ & Ani et al. [2015b] \\
\hline Palm oil & $\begin{array}{c}\text { MDA content } \\
\text { Lipid profile } \\
\text { Liver function enzymes } \\
\text { (Alanine transaminase-ALT, } \\
\text { Alkaline phosphatase-ALP) } \\
\text { Plasma and liver protein in wistar rat. }\end{array}$ & $\begin{array}{l}\text { MDA content, TCOL \& LDL } \\
\text { HDL } \\
\text { ALT \& ALP } \\
\text { Serum \& plasma protein }\end{array}$ & $\begin{array}{l}\downarrow \\
\uparrow \\
\downarrow\end{array}$ & $\begin{array}{l}\text { Lipid peroxidation; } \\
\text { cardiovascular } \\
\text { disease such as } \\
\text { atherosclerosis. }\end{array}$ & Falade et al. [2015] \\
\hline
\end{tabular}

Symbol interpretation: $\uparrow$-increased; $\downarrow$ - decreased; $\uparrow$ - no changes.

oil increased the serum parameters related to atherosclerosis in ovariectomized rats. In another study, it was suggested that chronic consumption of thermally-oxidized palm oil may cause anaemia and leukocytosis in rat [Mesembe et al., 2004]. This finding was further corroborated by Ani et al. [2015a] who reported that thermally-oxidized palm and groundnut 
oils may be detrimental to the body's haematological system as it causes alteration in $\mathrm{Hb}$ concentration, PCV, WBC count, neutrophil and lymphocyte counts.

Shastry et al. [2011] evaluated the effect of reused edible oils on vital organs of Wistar rats and concluded that reused sunflower and palm oils could be toxic and cause considerable damage to the vital organs of rats. Furthermore, Williams et al. [1999] studied the effect of ingestion of a meal rich in fat that had previously been used for deep-frying in a commercial food restaurant and observed an impairment in the arterial endothelial function in healthy men. Their findings suggested that consumption of deteriorated products of heated dietary oil may contribute to endothelial dysfunction in human. Endothelial dysfunction has been recognized as an early precursor of atherosclerosis [Mudau et al., 2012].

Jaarin et al. [2011] investigated the effects of heated palm and soy oils on blood pressure in rats and observed that repeatedly heated vegetable oils increased blood pressure, enhanced phenylephrine-induced contraction, decreased acetylcholine- and sodium nitroprusside-induced relaxations. The increased blood pressure induced by heated vegetable oils was linked to increased vascular reactivity and reduced nitric oxide (NO) level. The study also suggested that thermal oxidation may promote free radical generation thereby contributing to the pathogenesis of hypertension in rats. In a similar study, Hamsi et al. [2015] investigated the effect of consumption of fresh and heated virgin coconut oil on blood pressure and inflammatory biomarkers where it was discovered that repeatedly heated virgin coconut oil increased blood pressure and inflammatory markers such as intercellular adhesion molecule (ICAM-1), vascular cell adhesion molecule (VCAM-1), C-reactive protein (CRP), prostacyclin $\left(\mathrm{PGI}_{2}\right)$, and thromboxane $\mathrm{B}_{2}\left(\mathrm{TXB}_{2}\right)$. The result of the study suggests that thermally-oxidized cooking oils may induce inflammation which has been implicated in endothelial dysfunction, an important step in the development of atherosclerosis and carcinogenesis.

Furthermore, Leong et al. [2010] investigated the possible mechanism of elevation in blood pressure as a result of consumption of heated vegetable oil by evaluating the effect of consumption of heated soy oil on blood pressure, plasma NO, heme oxygenase (HO-1) and angiotensin-converting enzyme (ACE). The study recorded higher blood pressure and ACE activity as the plasma NO and HO-1 decreased. NO, an endothelium-derived relaxing factor is involved in the regulation of homeostasis of the vascular system to maintain its integrity [Leong et al., 2015]. A reduction in the level of NO compromises the integrity of the vascular system. Heme oxygenase is an inducible enzyme that catalyzes the conversion of pro-oxidative heme to iron, biliverdin and carbon II oxide (carbon monoxide). Biliverdin is further metabolized to bilirubin [Stocker et al., 1987] while carbon monoxide among other functions, is involved in the relaxation of blood vessels and platelet aggregation inhibition [Chlopicki et al., 2006; Achouh et al., 2008]. These vasoactive characteristics of HO-1 suggests its involvement in the regulation of blood pressure.

In a similar study, Leong et al. [2012] investigated the impact of repeatedly heated palm olein on the activity of blood pressure-regulating enzymes and lipid peroxidation in rats.
The study reported that repeatedly heated palm olein induced an increase in the levels of peroxide, ACE and likewise caused a decrease in HO-1, suggesting that consumption of thermally-oxidized palm olein may influence the catalytic functions of the enzymes linked with regulation of blood pressure thereby contributing to the development of hypertension. ACE catalyzes the conversion of the inactive angiotensin-I to angiotensin-II, an active vasoconstrictor. Furthermore, there are recent studies on the effects of consumption on fried foods including cooking oils on metabolic syndrome in human subjects [Guallar-Castillón et al., 2007; Sayon-Orea et al., 2013, 2014]. Sayon-Orea et al. [2014] has associated higher consumption of fried foods with a higher risk of central adiposity and blood pressure. Also higher prevalence of obesity, lower HDL-cholesterol and larger waist circumference have been linked with the consumption of fried foods [Guallar-Castillón et al., 2007; Sayon-Orea et al., 2013].

Consumption of thermally-oxidized sunflower oil has also been reported to cause an adverse effect on the liver and adipose tissue of rats, as hypertrophy of cells and cores were also observed in rats fed with the thermally-oxidized oil [Sadoudi et al., 2013]. If this finding would be applicable to human, the adverse biochemical and histological consequences of chronic consumption of thermally-oxidized cooking oils calls for a great concern.

Ani et al. [2015b] in one of their recent studies investigated the effect of chronic consumption of fresh and thermallyoxidized palm oil diet on the serum electrolytes, creatinine and urea as kidney function markers. The study revealed a significant change in the kidney function markers of rabbits fed with thermally-oxidized palm oil thereby suggesting a compromised renal status of the rabbits.

In our recent study [Falade et al., 2015] on the effect of consumption of thermally-oxidized palm oil on some biochemical parameters in rats; consumption of thermallyoxidized palm oil diets had deleterious effects on biochemical indices in rats. Specifically, an elevated MDA content was observed in both plasma and liver of rats fed with thermallyoxidized palm oil diet which was suggestive of free radical formation. Furthermore, an elevated total cholesterol and LDL which are risk factors of cardiovascular diseases was also reported in the study. Hence, we suggested that consumption of palm oil subjected to heating for long periods of time should be discouraged as it might have deleterious effects on human health.

\section{CONCLUSION}

Given the extensive study on thermal oxidation of cooking oils domestically and industrially, there is overwhelming evidence that thermal oxidation has deteriorative effects on cooking oils. Some of these effects include generation of very cytotoxic compounds; loss of carotenoid, phenolic compounds and vitamin $\mathrm{E}$, thus reducing the overall antioxidant properties of the oils and jeopardizing their nutritional essence and health benefits.

Furthermore, past and recent in vivo studies had suggested that consumption of various thermally-oxidized cooking oils is not healthy as it may negatively influence the lipid profile 
(increased LDL, decreased HDL and elevated cholesterol level); haematological system (alteration in the concentration of heamoglobin, PCV, WBC count, neutrophil and lymphocyte counts); kidney function; and induce lipid peroxidation and oxidative stress which have been linked with the development of various diseases including cancer, Alzheimer disease, myocardial infarction, kidney dysfunction, diabetes mellitus and its complications.

It can be deduced that thermal oxidation seems not to provide any health benefit, as it deteriorates cooking oils and the consumption of thermally-oxidized cooking oils may predispose consumers to various disease conditions that may ensue from free radical generation, and consequently resulting in deleterious effect on human health, suggesting the need for care in making choices of suitable cooking oils for a particular culinary activity based on their stability at high temperatures. Moreso, culinary activity should be carried out at low temperatures and for short periods to prevent generation of toxic oxidation products which may have adverse health effect. The need for more studies towards producing and developing cooking oils with improved heat stability through genetic modification and fortification become imperative and hereby proposed. Furthermore, the exploration of underutilized edible oils such as flaxseed oil, borage oil, camelina oil, amaranth oil and milk thistle oil as nutritional supplements in thermally-oxidized oil is imperative.

\section{RESEARCH FUNDING}

This work did not receive financial support in form of grant from any funding organization.

\section{CONFLICT OF INTERESTS}

The authors declare that there is no competing interest.

\section{REFERENCES}

1. Achouh P.E., Simonet S., Fabiani J.N., Verbeuren T.J., Carbon monoxide induces relaxation of human internal thoracic and radial arterial grafts. Interact. Cardiovasc. Thorac. Surg., 2008, 7, 959-962.

2. Adam S.K., Das S., Soelaiman I.N., Umar N.A., Jaarin K., Consumption of repeatedly heated soy oil increases the serum parameters related to atherosclerosis in ovariectomized rats. Tohoku J. Exp. Med., 2008b, 215, 219-226.

3. Adam S.K., Soelaiman I.N., Umar N.A., Mokhtar N., Mohamed N., Jaarin K., Effects of repeatedly heated palm oil on serum lipid profile, lipid peroxidation and homocysteine levels in a postmenopausal rat model. McGill J. Med., 2008a, 11, 145-151.

4. Adam S.K., Sulaiman N.A., Mat Top A.G., Jaarin K., Heating reduces vitamin E content in palm and soy oils. Malays. J. Biochem. Mol. Biol., 2007, 15 (2), 76-79.

5. Aladedunye F.A., Przybylski R., Degradation and nutritional quality changes of oil during frying. J. Am. Oil Chem. Soc., 2009, 86, 149-156.

6. Alarcon de la Lastra C., Barranco M.D., Motilova V., Herrerias J.M., Mediterranean diet and health: biological importance of olive oil. Curr. Pharm. Design., 2001, 7, 933-950.
7. Andrikopoulos N.K., Kalogeropoulos N., Falirea A., Barbagianni M.N., Performance of virgin olive oil and vegetable shortening during domestic deep-frying and pan-frying of potatoes. Int. J. Food Sci. Tech., 2002, 37 (2), 177-190.

8. Ani E.J., Nna V.U., Obi C.E., Udobong N.J., Comparative effects of thermoxidized palm oil and groundnut oil diets on some haematological parameters in albino wistar rats. Aust. J. Basic Appl. Sci., 2015a, 9 (5), 181-184.

9. Ani E.J., Nna V.U., Owu D.U., Osim E.E., Effect of chronic consumption of two forms of palm oil diet on serum electrolytes, creatinine and urea in rabbits. J. Appl. Pharm. Sci., 2015b, 5 (6), 115-119.

10. Attya M., Benabdelkamel H., Perri E., Russo A., Sindona G., Effects of conventional heating on the stability of major olive oil phenolic compounds by tandem mass spectrometry and isotope dilution assay. Molecules, 2010, 15, 8734-8746.

11. Blekas G., Boskou D., Phytosterols and stability of frying oils. 1999, in: Frying of Food. (eds. D.Boskou, I. Elmadfa). Technomic Publishing Co. Inc., Lancaster, pp. 205-222.

12. Boskou D., Culinary applications. 2006, in: Olive Oil Chemistry and Technology (ed. D. Boskou). AOCS Press, Champaign, Illinois, pp. 243-248.

13. Brenes M., Garciäa A., Dobarganes M.C., Velasco J., Romero C.N., Influence of thermal treatments simulating cooking processes on the polyphenol content in virgin olive oil. J Agric. Food Chem., 2002, 50, 5962-5967.

14. Carrasco-Pancorbo A., Cerretani L., Bendini A., Segura-Carretero A., Lercker G., Fernaändez-Gutieärrez A., Evaluation of the influence of thermal oxidation on the phenolic composition and on the antioxidant activity of extra-virgin olive oils. J. Agric. Food Chem., 2007, 55, 4771-4780.

15. Chlopicki S., Olszanecki K., Marcinkiewicz E., Lomnicka M., Motterlini R., Carbon monoxide released by CORM-3 inhibits human platelets by a mechanism independent of soluble guanylate cyclase. Cardiovasc. Res., 2006, 71, 393-401.

16. Choe E., Min D.B., Chemistry of deep-fat frying oils. J. Food Sci., 2007, 72 (5), R77-R86.

17. Chong Y.H., Ng T.K.W., Effects of palm oil on cardiovascular risk. Med. J. Malaysia, 1991, 46, 1.

18. Cicerale S., Lucas, L.J., Keast R.S.J., Antimicrobial, antioxidant and anti-inflammatory phenolic activities in extra virgin olive oil. Curr. Opin. Biotechnol., 2012, 23, 129-135.

19. Dittrich M., Jahreis G., Bothor K. et al., Benefits of foods supplemented with vegetable oils rich in alpha-linolenic, stearidonic or docosahexaenoic acid in hypertriglyceridemic subjects: a double-blind, randomized, controlled trial. Eur. J. Nutr., 2015, 54, 881-893.

20. Dobarganes C., Márquez-Ruiz G., Possible adverse effects of frying with vegetable oils. British J. Nutr., 2015, 113, S49-S57.

21. Falade A.O., Oboh G., Thermal oxidation induces lipid peroxidation and changes in the physico-chemical properties and $\beta$-carotene content of arachis oil. Int. J. Food Sci., 2015, dx.doi.org/10.1155/2015/806524.

22. Falade A.O., Oboh G., Ademiluyi A.O., Odubanjo O.V., Consumption of thermally oxidized palm oil diets alters biochemical indices rats. Beni Suef University J. Basic Appl. Sci., 2015, 4 (2), 150-156.

23. Farmer E.E., Davoine C., Reactive electrophile species. Curr. Opin. Plant Biol., 2007, 10 (4), 380-6. 
24. Fullana A., Carbonell-Barrachina A.A., Sidhu S., Comparison of volatile aldehydes present in the cooking fumes of extra virgin olive, olive, and canola oils. J. Agric. Food Chem., 2004, 52, 5207-5214.

25. Giacco F., Brownlee M., Oxidative stress and diabetic complications. Circ. Res., 2010, 107 (9), 1058-1070.

26. Guallar-Castillon P., Rodríguez-Artalejo F., Lopez-Garcia E. et al., Intake of fried foods is associated with obesity in the cohort of Spanish adults from the European prospective investigation into cancer and nutrirtion. Am. J. Clin. Nutr., 2007, 86, 198-205.

27. Gupta M.K., Frying oil. 2005, in: Edible Oil and Food Products: Products and Applications (ed. F. Shahidi). John Wiley \& Sons, Hoboken, NJ, USA, pp. 1-31.

28. Halliwell B., Oxidative stress and cancer: have we moved forward. Biochem. J., 2007, 401 (1), 1-11.

29. Halvorsen B.L., Blomhoff R., Determination of lipid oxidation products in vegetable oils and marine omega-3 supplements. Food Nutr. Res., 2011, 55, 5792, doi: 10.3402/fnr.v55i0.5792.

30. Hamsi M.A., Othman F., Das S., Kamisah Y., Thent Z.C., Qodriyah H.M., Zakaria Z., Emran A., Subermaniam K., Jaarin K., Effect of consumption of fresh and heated virgin coconut oil on the blood pressure and inflammatory biomarkers: An experimental study in Sprague Dawley rats. Alexandria J. Med., 2015, 51, 53-63.

31. Innis S.M., Dyer R.A., Dietary canola oil alters hematological indices and blood lipids in neonatal piglets fed formula. J. Nutr., 1999, 129 (7), 1261-1268.

32. Ivanov D.S., Lević J.D., Sredanović S.A., Fatty acid composition of various soybean products. Food Feed Res., 2010, 37 (2), 65-70.

33. Jaarin K., Mustafa M.R., Leong X.F., The effects of heated vegetable oils on blood pressure in rats. Clinics, 2011, 66 (12), 2125-2132.

34. Katragadda H.R., Fullana A.S., Sidhu S., Carbonell-Barrachina A.A., Emissions of volatile aldehydes from heated cooking oils. Food Chem., 2010, 120, 59-65.

35. Leong X.F., Mustafa M.R., Das S., Jaarin K., Association of elevated blood pressure and impaired vasorelaxation in experimental Sprague-Dawley rats fed with heated vegetable oil. Lipids Health Dis., 2010, 9, 66.

36. Leong X.F., Ng C.U., Jaarin K., Mustafa M.R., Effects of repeated heating of cooking oils on antioxidant content and endothelial function. Austin J. Pharmacol. Ther., 2015, 3 (2), 1068.

37. Leong X.F., Salimon J., Mustafa M.R., Jaarin K., Effect of repeatedly heated palm olein on blood pressure-regulating enzymes activity and lipid peroxidation in rats. Malays. J. Med. Sci., 2012, 19 (1), 20-29.

38. Marinova E.M., Seizova K.A., Totseva I.R., Panayotova S.S., Marekov I.N., Momchilova S.M., Oxidative changes in some vegetable oils during heating at frying temperature. Bulg. Chem. Commun., 2012, 44 (1), 57-63.

39. Márquez-Ruiz G., Pérez-Caminò M.C., Dobarganes M.C., Digestibility of fatty acid monomers, dimers and polymers in the rat. J. Am. Oil Chem. Soc., 1992, 69, 930-934.

40. Márquez-Ruiz G., Pérez-Caminò M.C., Dobarganes M.C., Evaluation of hydrolysis and absorption of thermally oxidized olive oil in non-absorbed lipids in the rat. Ann. Nutr. Metabol., 1993, 37, 121-128.
41. Massy Z.A., Stenvinkel P., Drueke T.B., The role of oxidative stress in chronic kidney disease. Semin. Dialysis, 2009, 22 (4), 405-408.

42. Matthäus B., Use of palm oil for frying in comparison with other high-stability oils. Eur. J. Lipid Sci. Tech., 2007, 109 (4), 400-9.

43. Mba O.I., Dumont M., Ngadi M., Palm oil: processing, characterization and utilization in the food industry - A review. Food Biosci., 2015, 10, 26-41.

44. Meacher D.M., Menzel D.B., Depletion in lung cells by low-molecular weight aldehydes. Cell Biol. Toxicol., 1999, 15, 163-171.

45. Mesembe O.E., Ibanga I., Osim E.E., The effects of fresh and thermoxidized palm oil diets on some haematological indices in rat. Niger. J. Physiol. Sci., 2004, 19 (1-2), 86-91.

46. Mudau M., Genis A., Lochner A., Strijdom H., Endothelial dysfunction: the early predictor of atherosclerosis. Cardiovasc. J. Afr., 2012, 24 (4), 222-231.

47. Mukherjee S., Mitra A., Health effects of palm oil. J. Hum. Ecol. 2009, 26 (3), 197-203.

48. Nakbi A., Tayeb W., Dabbou S., Chargui I., Issaoui M., Zakhama A., Miled, A., Hypolipidemic and antioxidant activities of virgin olive oil and its fractions in 2, 4-dichlorophenoxy acetic acid-treated rats. Nutr., 2012, 28, 81-91.

49. Naz S., Siddiqi R., Sheikh H., Sayeed S.A., Deterioration of olive, corn and soybean oils due to air, light, heat and deep-frying. Food Res. Int., 2005, 38, 127-134.

50. Oboh G., Falade A.O., Ademiluyi A.O., Effect of thermal oxidation on the physico-chemical properties, malondialdehyde and carotenoid contents of palm oil. Riv. Ital. Sostanze Gr., 2014, 91 (1), 59-65.

51. O'Brien R., Fats and oils formulating and processing for applications. Formulating and Processing for Applications ( $3^{\text {rd }}$ ed.). CRC Press. 2008, pp. 37-40.

52. Odia S.J., Ofori S., Maduka O., Palm oil and the heart: A review. World J. Cardiol., 2015, 7 (3), 144-149.

53. Oil World, Oil World Annual, 2013. Retrieved from [http://www. oilworld.biz/app.php], Released June 2013.

54. Olivero-David R., Paduano A., Fogliano V. et al., Effect of thermally oxidized oil and fasting status on the short-term digestibility of ketolinoleic acids and total oxidized fatty acids in rats. J. Agric. Food Chem., 2011, 59, 4684-4691.

55. Ong A.S., Goh S.H., Palm oil: a healthful and cost-effective dietary component. Food Nutr. Bull., 2002, 23, 11-22.

56. Onyeali E.U., Onwuchekwa A.C., Monago C.C., Monanu M.O., Plasma lipid profile of wistar albino rats fed palm oil supplemented diets. Int. J. Biol. Chem. Sci., 2010, 4 (4), 1163-1169.

57. Owen R.W., Giacosa A., Hull W.E., Haubner R., Wurtele G., Spiegelhalder B., Bartsch H., Olive-oil consumption and health: the possible role of antioxidants. Lancet Oncol., 2000, 1, 107-112.

58. Oyewole O.E., Amosu A.M., Public health nutrition concerns on consumption of red palm-oil (RPO): the scientific facts from literature. Afr. J. Med. Med. Sci., 2010, 39, 255-262.

59. Peers K.E., Swoboda P.A.T., Deterioration of sunflower oil under simulated frying conditions and during small scale frying of potato chips. J. Sci. Food Agric., 1982, 33 (4), 389-395.

60. Pohanka M., Alzheimer's disease and oxidative stress: a review. Curr. Med. Chem., 2014, 21 (3), 356-364.

61. Ramana K.V., Srivastava S., Singhal S.S., Lipid peroxidation products in human health and disease. Oxid. Med. Cell Longev., 2013, dx.doi.org/10.1155/2013/583438. 
62. Ramond A., Godin-Ribuot D., Ribuot C., Totoson P., Koritchneva I., Cachot S., Levy P., Joyeux-Faure M., Oxidative stress mediates cardiac infarction aggravation induced by intermittent hypoxia. Fundam. Clin. Pharmacol., 2013, 27 (3), 252-261.

63. Rogalski M., Szterk A., Oxidative stability of $\alpha$-linolenic acid in corn chips enriched with linseed oil pro/antioxidative activity of tocopherol. J. Am. Oil Chem. Soc., 2015, 92 (10), 1461-1471.

64. Sadoudi R., Ammouche A., Ali A.D., Effect of ingestion of thermally oxidized sunflower oil on the fatty acid composition and histological alteration of rat liver and adipose tissue in development. Afr. J. Agric. Res., 2013, 8 (24), 3107-3112.

65. Sadoudi R., Ammouche A., Ali A.D., Thermal oxidative alteration of sunflower oil. Afr. J. Food Sci., 2014, 8 (3), 116-121.

66. Salar A., Faghih S., Pishdad G.R., Rice bran oil and canola oil improve blood lipids compared to sunflower oil in women with type-2 diabetes: a randomized, single-blind controlled trial. J. Clin. Lipidol., 2016, 10, 299-305.

67. Sayon-Orea C., Bes-Rastrollo M., Basterra-Gortari F.J. et al., Consumption of fried foods and weight gain in a Mediterranean cohort: the SUN project. Nutr. Metab. Cardiovasc. Dis., 2013 , 23, 144-150.

68. Sayon-Orea C., Martínez-González M.A., Gea A. et al., Consumption of fried foods and risk of metabolic syndrome: the SUN cohort study. Clin. Nutr., 2014, 33, 545-549.

69. Seppanen C.M., Song Q.H., Csallany A.S., The antioxidant functions of tocopherol and tocotrienol homologues in oils, fats and food systems. J. Am. Oil Chem. Soc. 2010, 87, 469-481.

70. Shastry C.S., Patel N.A., Joshi H., Aswathanarayana B.J., Evaluation of effect of reused edible oils on vital organs of wistar rats. Nitte University J. Health Sci., 2011, 1 (4), 10-15.

71. Stocker R., Yamamoto Y., Mc Donagh A.F., Glazer A.N., Ames B.N., Bilirubin is antioxidant of possible physiological importance. Science, 1987, 235, 1043-1046.
72. Szterk A., Rogalski M., Szymborski T., The impact of linseed oil lipids on the physical properties of corn crisps and the possibility of obtaining crisps enriched with n-3 fatty acids. J. Am. Oil Chem. Soc., 2015, 92 (8), 1195-1203.

73. Tripoli E., Giammanco M., Tabacchi G., Di Majo D., Giammanco S., La Guardia M., The phenolic compounds of olive oil: structure, biological activity and beneficial effects on human health. Nutr. Res. Rev., 2005, 18, 98-112.

74. USDA National Nutrient Database for Standard Reference. 2008; Release 21.

75. Vaskova H., Buckova M., Thermal degradation of vegetable oils: spectroscopic measurement and analysis. Procedia Eng., 2015, 100, 630-635.

76. Wang C., Harris W.S., Chung M., Lichtenstein A.H., Balk E.M., Kupelnick B., Jordan H.S., Lau J., n-3 Fatty acids from fish or fish-oil supplements, but not alpha-linolenic acid, benefit cardiovascular disease outcomes in primary- and secondary-prevention studies: a systematic review. Am. J. Clin. Nutr., 2006, 84 (1), 5-17.

77. Warner K., Chemical and physical reactions in oil during frying. 2004, in: Frying Technology and Practice (eds. M.K. Gupta, K. Warner, P. J. White). AOCS., Champaign, pp. 16-28.

78. Williams M.J., Sutherland W.H., McCormick M.P., de Jong S.A., Walker R.J., Wilkins G.T., Impaired endothelial function following a meal rich in used cooking fat. J. Am. Coll. Cardiol., 1999, 33, 1050-1055.

79. WHO, World Health Organization, Diet nutrition and the prevention of chronic diseases. Report. 2003, 82-88.

80. Yang H., Jin X., Kie Lam C.W., Yan S.K., Oxidative stress and diabetes mellitus. Clin. Chem. Lab. Med., 2011, 49 (11), 1773-1782.

Submitted: 17 March 2016. Revised: 3 June 2016. Accepted: 15 July 2016. Published on-line: 4 November 2016. 
